\title{
Fading Opportunities
}

Hong Kong in the context of regional integration

\section{Tai-lok Lui}

\section{OpenEdition}

\section{Journals}

Electronic version

URL: http://journals.openedition.org/chinaperspectives/6380

DOI: 10.4000/chinaperspectives.6380

ISSN: 1996-4617

\section{Publisher}

Centre d'étude français sur la Chine contemporaine

\section{Printed version}

Date of publication: 1 March 2014

Number of pages: $35-42$

ISSN: 2070-3449

\section{Electronic reference}

Tai-lok Lui, « Fading Opportunities », China Perspectives [Online], 2014/1 | 2014, Online since 01 January 2017, connection on 28 October 2019. URL : http://journals.openedition.org/ chinaperspectives/6380 ; DOI : 10.4000/chinaperspectives.6380

(C) All rights reserved 


\title{
Fading Opportunities
}

\author{
Hong Kong in the context of regional integration
}

\section{TAI-LOK LUI}

\begin{abstract}
There is a missing piece in the puzzle of social development in post-1997 Hong Kong: regional and national integration. For a long time it was envisaged that while Hong Kong would remain relatively secluded from the mainland, it could seize the opportunities, evidenced in the massive relocation of manufacturing plants to the Pearl River Delta since the mid-1980s, presented by China's economic reform. However, before long, with the deepening of China's market reform and its emergence as a new economic power, Hong Kong was caught unprepared for its integration into the motherland. Growing tensions between mainlanders and Hong Kong people have already received considerable media attention. But what has somehow escaped people's attention is that the expected opening of new opportunities for Hong Kong people on the mainland has not fully materialised. In this paper, we shall look at Hong Kong's current status in realising the expected opportunities to be created in the process of China's economic development and Hong Kong's further integration into the process of national development. Drawing upon official statistics on Hong Kong residents working in mainland China, it is suggested that, instead of seeing more Hong Kong residents finding the mainland to be a newly developed environment for career development, the trend has reversed.
\end{abstract}

KEYWORDS: regional integration, economic integration, manufacturing relocation, "China opportunity," Hong Kong residents working in mainland China.

\section{Introduction}

A s Hong Kong people nervously watched Britain and China negotiating over the political future of the British colony in the 1980s, the major concern was economic prosperity. Few people had much faith in the idea of "One Country, Two Systems" (a proposal put forward by China partially to pacify the business sector and avoid a drastic outflow of capital), worrying that the socialist economy would undermine the dynamism of Hong Kong's free-market capitalism. Many, especially those who left China immediately after 1949 and during various waves of massive illegal migration to the colony (such as in the early 1960s, triggered by the Great Leap Forward campaign), also had fresh memories of the political aftermath of socialist authoritarianism. The foci of people's fear primarily fell upon the domains of economics (an erosion of market capitalism) and politics (political suppression and a threat to personal freedom). Few paid serious attention to the fact that on 1 July 1997, when Hong Kong formally became part of China, some kind of integration, be it at the national or the regional level, was inevitable. As a result, the wider (socio-economic, cultural, and political) implications of regional or national integration were totally out of the picture. The neglect of this concern went largely unnoticed until 2003. From then onwards, however, there emerged a new social agenda in the changing mainland-Hong Kong relationship.

Many (see, for example, Chi Kit Chan in this special issue) have discussed the challenges posed by regional and national integration. Such challenges are manifested in the area of population flows (from the 35 million inbound tourists from the mainland in 2012 to the issue of babies born to non-local parents) and emerging tensions and conflicts between locals and mainlanders. But few bother to look at the promises that have not materialised. For instance, after 1997, the leaders of the Hong Kong Special Administrative Re- gion (SAR) government placed increasingly emphasis on capitalising on the opportunities created by the vibrant Chinese economy. ${ }^{\left({ }^{1}\right)}$ It was suggested that Hong Kong, with backing from the motherland (beikao zuguo 背靠祖 國), would have a bright future in the face of a globalising world. (2) It was simplistically believed that Hong Kong and its people, if they realised the potential in the mainland and were willing to seize the opportunities there, would automatically be able to ride on the wave of China's growing economy. Young people were therefore strongly advised to brush up on their Mandarin, to get familiar with current developments in their country, and to develop their will and commitment for a challenging career across the border in order to capitalise on the demand for talent in a globalising China. Quite often, a globalising China, regional and national integration, and growing opportunities offered to Hong Kong were simply taken as part of a formula for the SAR's future success. The connections among these three areas of socio-economic change were often assumed without further reflection. As I intend to show in the following discussion, the demand for talent from Hong Kong for business and professional activities in China has not followed the pattern of growth once envisaged by many political and business leaders. Current development in terms of Hong Kong residents working in China is gradually departing from

1. This was, again, underlined in the 2014 policy address made by the Chief Executive. In quoting an example of a young entrepreneur who started his business venture in Guangxi, Leung Chun-ying emphasised that "with determination and tenacity, and by capitalising on the opportunities at home and abroad, young people can build a promising career in various markets and industries, new or traditional." See www.policyaddress.gov.hk/2014/eng/p12.html (accessed on 10 February 2014).

2. The idea of working towards closer economic cooperation between Hong Kong and the mainland caught media attention during a meeting between SAR Chief Executive Tung Chee-hwa and Beijing leader jiang Zemin in Shanghai in 2001. Beikao zuguo was seen as a Hong Kong's advantage under the arrangement of "One Country, Two Systems." It is believed that Tung Chee-hwa played an active and important role in the facilitation of what later materialised as the CEPA. See http://paper.wenweipo.com/2001/10/24/WW0110240004.htm (accessed on 10 February 2014). 
the promising model commonly observed in the 1980s and 1990s, when China had just re-opened its door to the outside world and to deepening market reform.

In this paper, we shall focus on one aspect of this changing mainlandHong Kong relationship, namely how Hong Kong is gradually finding difficulty capitalising on opportunities developing in China to provide its people with promising careers in business and professional services. Drawing upon statistics collected by the Census and Statistics Department of the Hong Kong SAR government on Hong Kong residents working in mainland China, I will show how the so-called "China opportunity," in terms of Hong Kong people working on the mainland, has gradually reached a threshold. (3) Since then, beikao zuguo has no longer delivered the expected outcome.

\section{Post-1997 Hong Kong}

The SARS outbreak in 2003 and the resulting economic recession brought about two major changes. First, Mr. Tung Chee-hwa did not finish his term of office, and Beijing appointed Mr. Donald Tsang to be the new Chief Executive. Second, the CEPA (Mainland and Hong Kong Closer Economic Partnership Arrangement) was signed, granting Hong Kong better access to the mainland market through a free trade arrangement. Among the many items on the CEPA, the Individual Visit Scheme (IVS) opened Hong Kong to a market of 270 million residents with permanent household registration in 49 cities. ${ }^{(4)}$ The number of mainland tourists visiting Hong Kong rose from 12 million in 2004 to about 18 million in 2009. From 2009 onwards, there was an increase of roughly six million per year, reaching the figure of 35 million in 2012. Among these 35 million mainland tourists in 2012 , some 18 million were day-trippers (meaning they returned home on the same day). Increasingly, the traffic between Hong Kong and the mainland intensified.

The rise of two-way trans-border traffic and population movement created opportunities for mainland parents to give birth in Hong Kong. The number of births by mainland women whose spouses were not Hong Kong permanent residents rose from 2,070 in 2003 to 18,816 in 2007, and between 2007 and 2011, the figure doubled to 35,736. These babies were entitled to the right of permanent residency in Hong Kong. Public concern over a shortage of places in local kindergartens in October 2013 (the beginning of the annual admission exercise), particularly in areas near Shenzhen, were partly a response to a significant increase in so-called shuangfei (meaning babies whose parents were both non-locals) in 2008-2012.

Most observers have little difficulties in recognising the overwhelming volume and impact of this growing two-way trans-border traffic. They are also well aware of the fact that such a population movement and its concomitant regional integration process were not anticipated in the original thinking of Hong Kong's return to China. The idea of "One Country, Two Systems" implies the maintenance of a certain economic, social, and political distance (if not segregation) between Hong Kong and the mainland. During the course of the political transition, it was emphasised that Hong Kong's status as a highly autonomous SAR was the institutional arrangement that would ensure its prosperity and stability by being kept apart from the mainland's socialist economy and authoritarian political system. People from the mainland would be required to possess entry permits for Hong Kong, and if there was to be substantial traffic between the mainland and the SAR, it would most likely be a continuation of the economic integration driven by the relocation of Hong Kong's manufacturing to the Pearl River Delta (PRD). The question of regional integration was never on the agenda. More interestingly, few observers have acknowledged that they not only failed to anticipate the growing influx of mainlanders to Hong Kong, but they also paid too little attention to the changing prospects of Hong Kong people capitalising on opportunities in the rapidly changing Chinese economy. Very often, the idea of Hong Kong entrepreneurs, professionals, and managers still being much in demand for business in China or Chinese enterprises learning catch up with a globalising economic world is still taken for granted. As a result, the growing strength of China's position in the world economy is uncritically taken as a source of optimism for Hong Kong's economic development as well as in terms of employment opportunities for its people. As we shall see in the following discussion, this optimistic assumption is simply not supported by empirical evidence. Indeed, one of the major challenges facing Hong Kong is that increasingly, the further liberalisation of the Chinese economy does not necessarily result in new openings for Hong Kong people. Despite its export of investments to the Pearl River Delta and many other parts of China, Hong Kong has actually created a much smaller spatial sphere of socio-economic influence than expected, at least in terms of employment. The image of Hong Kong-Guangdong as a global-city region may make sense to Hong Kong investors taking advantage of new-found resources resulting from the mainland's economic reform and marketisation. Yet this new space for capital has not been fully translated into opportunities for all classes of Hong Kong people. The limitations of the strategy of beikao zuguo are becoming apparent.

\section{Opportunities: Found and faded}

The early 1980s witnessed a gradual recognition that the neighbouring region across the border might well be Hong Kong's newly discovered hinterland. All this began in 1978, when China launched its economic reform and the programme of the "Four Modernisations." Hong Kong played a critical role in facilitating the transformation in China's socialist economy. It was China's "window to the world," through which the changing socialist economy acquired modern technology and know-how, picked up new management practices, and drew outside investment. More importantly, Hong Kong itself was a very important source, and indeed the main source, of foreign direct investments (FDIs) for Guangdong. Investment from Hong Kong

3. There are three different sets of statistics gathered by the Census and Statistics Department that would assist us in understanding the opportunities created by mainland China for Hong Kong residents to seek employment across the border. The focus of this paper will be on Hong Kong residents working in mainland China. The other source of information is surveys looking at "Hong Kong residents having resided/having stayed substantially" on the mainland. And thirdly, the 2011 Census covered mobile residents. Mobile residents are "Hong Kong Permanent Residents who have stayed in Hong Kong for at least one month but less than three months during the six months before or for at least one month but less than three months during the six months after the reference moment, regardless of whether they were in Hong Kong or not at the reference moment." See Census and Statistics Department, 2011 Population Census Main Report: Volume 1, Hong Kong, Census and Statistics Department, 2012, p. 3. Among the 212,235 mobile residents recorded in 2011,87,152 were economically active and 55,856 worked in mainland China. All three sets of statistics provide only a glimpse of Hong Kong residents finding employment opportunities outside of Hong Kong. The major limitation of the surveys carried out by the Census and Statistics Department is that they by definition cannot fully cover all Hong Kong residents who have left for good and have permanently settled in a new host society. What the existing statistics can primarily tell us is about the conditions of Hong Kong residents, be they mobile residents, those who have resided on the mainland, or those who work across the border, who have still maintained their connections (most notably by having a period of stay in the SAR within a specified period of time) with Hong Kong. Such a limitation notwithstanding, the survey findings on Hong Kong residents working on the mainland do allow us to examine at least one form of opportunity opened by the mainland economy to Hong Kong's residents.

4. The IVS is only one of the channels through which mainland tourists can visit Hong Kong. They can also do so by joining package tours. The establishment of the IVS signifies a widening of channels and an enhancement of flexibility for Hong Kong to capture the growing tourism consumption of the mainland. 


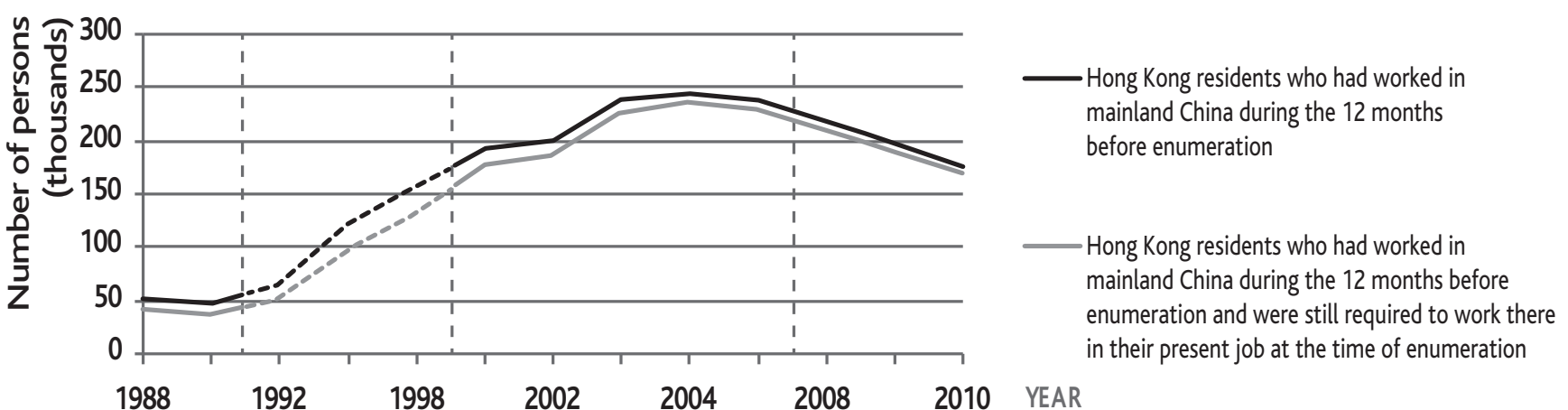

Source: Census and Statistics Department, "Hong Kong Residents Working in the Mainland of China," various years.

began flowing into the Pearl River Delta in the early 1980s. But as observed by Victor Sit and Chun Yang, the mid-1980s onward not only saw a further increase in the inflow of FDI, but also "a large number of small and mediumsized Hong Kong enterprises shifted their labour intensive manufacturing into the Delta, leading to a new phase of foreign investment that has had a profound impact on urbanisation there. [...] By the end of the 1980s, the Delta had become a large production base for Hong Kong, and Hong Konginvested manufacturing enterprises there employed 3 million people, about five times the manufacturing employment of Hong Kong itself." (5)

The galloping pace of industrial relocation further accelerated in the next decade. A rather conservative estimate suggested that in Guangdong alone, Hong Kong manufacturers operated 25,000 factories and employed three million workers in 1993. ${ }^{(6)}$ Another estimate was that in 1996, the size of the workforce of Hong Kong manufacturers in Guangdong was eight times that in Hong Kong proper. ${ }^{(7)}$ According to a survey conducted by the Federation of Hong Kong Industries, by 2002, the number of workers in Guangdong employed under Hong Kong-based companies rose to more than 10 million. ${ }^{(8)}$ Compared with the figures suggested by Sit and Yang (see above), in around ten years' time, the Guangdong workforce working for Hong Kong companies increased more than threefold. (9) Such a large-scale relocation of the production base to the Pearl River Delta gave rise to a new form of spatial division of labour characterised as "front shop, back factory," with Hong Kong focusing on its strengths in commercial networking, business services, and marketing, and the Delta providing manufacturers with cheap land and labour for production. This helped Hong Kong maintain its competitiveness, at least in the short run, without actually carrying out technological upgrading. Hong Kong manufacturing continued to be largely labour intensive, but with the benefit of abundant supplies of cheap labour in the Pearl River Delta and an expansion of the scale of production after relocation, it fared very well in the 1990s. ${ }^{100}$ Of course, with the benefit of hindsight, we understand that such a restructuring strategy, namely by relocation rather than technological upgrading, became a source of future problems for Hong Kong manufacturers and for industrial development in Guangdong in the decade to follow. But until then, Hong Kong capitalised on this opportunity and further strengthened its development in producer services and business services. ${ }^{(11)}$ Hong Kong rapidly transformed itself into a service-oriented economy, as reflected in Hong Kong's changing domestic economic structure. Accounting for almost 40\% of employment in the local economy at its peak in 1981, manufacturing dropped to less than $10 \%$ by the turn of the century. The number of manufacturing establishments fell from 51,671 in 1988 to 20,380 in 1999.
As a response to this compressed process of industrial restructuring and the formation of a new spatial division of labour in the flow of economic activity between the mainland and Hong Kong, the government of Hong Kong began collecting information on Hong Kong residents working in mainland China in 1988. ${ }^{(12)}$ This reflected the changing economic and employment environment of Hong Kong since the re-opening of the Chinese economy in 1978 as well as the government's recognition of emerging issues (e.g., the coverage of the employment ordinances) created by such changes. In surveys carried out by the Census and Statistics Department, Hong Kong residents working in the mainland refers to:

...employed persons in the Hong Kong Resident Population who were required to work in the mainland in their present job, irrespective of the number of times they had travelled to work in the mainland during the 12-month period and the duration of each stay. However, persons who went to the mainland only for conducting business negotiations and inspection of business, and/or attending trade fairs, meetings and business-related entertainment were not regarded as "working in the mainland." Transport workers commuting between Hong Kong and the mainland, and fishermen or seamen working within the waters of the mainland were also excluded." (13)

5. Victor F. S. Sit and Chun Yang, "Foreign-investment-induced exo-urbanisation in the Pearl River Delta, China," Urban Studies, Vol. 34, No. 4, 1997, p. 651

6. Federation of Hong Kong Industries, Investment in China, Hong Kong, Federation of Hong Kong Industries, 1993, p. 3.

7. Suzanne Berger and Richard K. Lester (eds), Made by Hong Kong, Hong Kong, Oxford University Press, 1997, p. 24

8. Federation of Hong Kong Industries, Made in PRD: The Changing Face of HK Manufacturers, Hong Kong, Federation of Hong Kong Industries, 2003.

9. Of course, Hong Kong investments are by no means confined to the Pearl River Delta. It was suggested that at the end of 2005, the accumulated amount of capital invested in the Yangtze River Delta rose to US\$61 million, accounting for almost $60 \%$ of the investments in Guangdong. See Federation of Hong Kong Industries, Made in PRD: Challenges and Opportunities for HK Industry, Hong Kong, Federation of Hong Kong Industries, 2007, p. 17.

10. Tai-lok Lui and Stephen W.K. Chiu, "A tale of two industries: The restructuring of Hong Kong's garment-making and electronics industries," Environment and Planning A, Vol. 26 No. 1, 1994; Stephen W.K. Chiu and Tai-lok Lui, Hong Kong: Becoming a Chinese Global City, London, Routledge, 2009.

11. Zhigang Tao and Yue Chim Richard Wong, "Hong Kong: From an industrialised city to a centre of manufacturing-related services," Urban Studies, Vol. 39, No. 12, 2002.

12. This kind of survey was first carried out in October-December 1988. From then onwards, similar enquiries were conducted periodically via the General Household Survey.

13. Census and Statistics Department, "Hong Kong Residents Working in the Mainland of China, 19952005," Hong Kong Monthly Digest of Statistics, January 2006, p. FB2. 


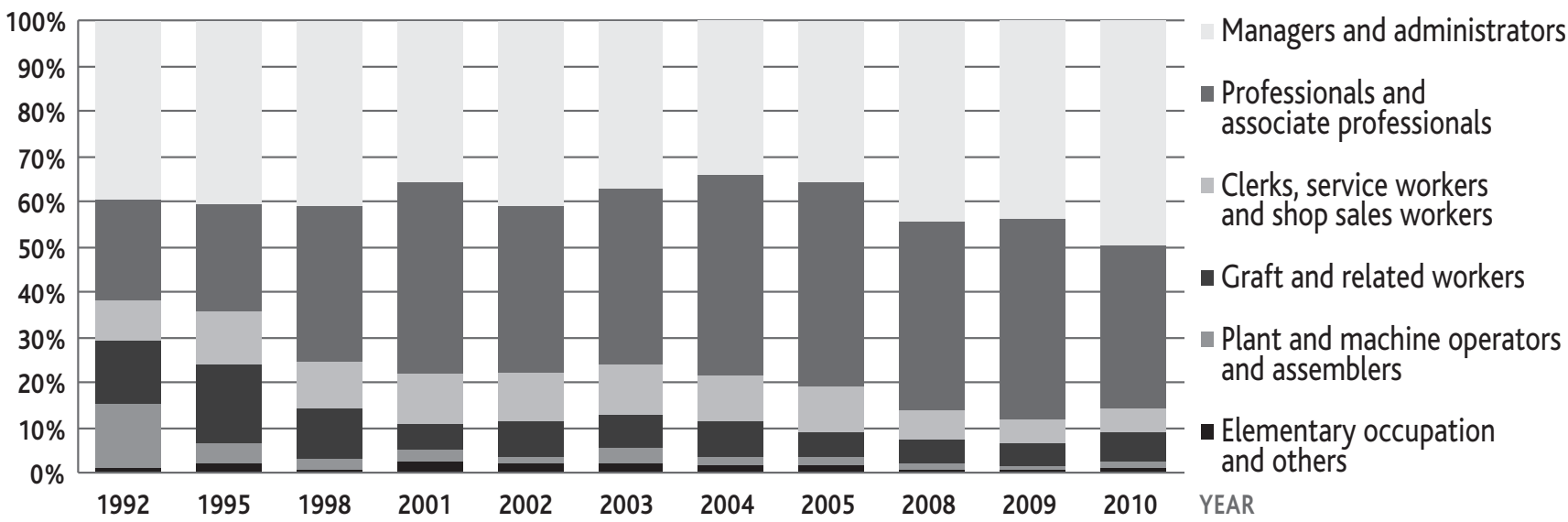

Source: Census and Statistics Department, "Hong Kong Residents Working in the Mainland of China," various years.

In this connection, it is important to note that Hong Kong Permanent Residents who stayed in Hong Kong "for less than one month during the six months before and after the time of enumeration," for example those who had already moved to and lived on the mainland on a long-term basis, were not covered by the surveys. ${ }^{(14)}$ But this will not affect our discussion and analysis in the following section. ${ }^{(15)}$

Echoing what was discussed above concerning industrial relocation and the changing economic linkage between Hong Kong and the mainland, it is observed that the number of Hong Kong residents working on the mainland grew significantly in the 1990s (see Graph 1). When the government first began to collect statistics on this topic, the survey findings showed only 52,300 Hong Kong residents. There was then a slight drop in 1989, and then the figure bounced back and rose slightly to 64,200 in 1992. But from then onwards the figure increased almost threefold to 190,800 in 2001. It reached its peak in 2004 with a record of 244,000 . Since then, the figure has dropped in subsequent surveys. In 2010, it was found that there were 175,100 Hong Kong residents working on the mainland.

That the number of Hong Kong residents working on the mainland has not continued to rise as China has become an emergent world economic power no doubt comes as a surprise to many people. A closer look at the composition of Hong Kong residents working in China gives us some hints of how the opportunities once opened by the development of China are gradually fading away. Graph 2 reports the distribution of occupations among Hong Kong residents who work on the mainland. It is interesting to observe that the number of people engaged in so-called blue-collar jobs (for example, according to the classification adopted by the Census and Statistics Department, "craft and related workers" and "plant and machine operators and assemblers") drastically decreased from $28.4 \%$ in 1992 to $7.6 \%$ in 2010. ${ }^{(16)}$ This indicates two important features of the opportunities once created by the marketisation of the Chinese economy.

First, it shows that very quickly, many Hong Kong workers, to a large extent irrespective of their skill and experience, were replaced by local workers in the Pearl River Delta. In the 1980s and 1990s, the relocation process required Hong Kong manufacturers to bring in experienced and skilled workers to help ensure the proper training of workers, quality control, and a smooth function of the production process. Some of these experienced workers were promoted to skilled workers, foremen/supervisors, and factory managers to assist employers in managing a workforce that was unfamiliar with factory discipline and had little understanding of quality assurance. But as Delta workers gradually picked up skills and know-how, they (presumably at least partly due to cost considerations) displaced those who had originally come from Hong Kong. The demand for Hong Kong personnel working on production-related processes dropped accordingly, as shown in the statistics reported in Graph 2.

Second, and more importantly, the main driving forces behind the processes of industrial relocation were rising production costs in Hong Kong (making the Delta's abundant supplies of cheap land and labour attractive) and the organisational inertia of Hong Kong's manufacturers in carrying out major organisational restructuring. (17) That Hong Kong's manufacturers were eager to make the best use of cheap labour across the border meant that, with capital being mobile, workers were left behind. While many of these manufacturers expanded their scale of production after relocation, such initiatives had little or no impact on manufacturing employment in Hong Kong. The increased hiring of production workers in the Delta neither improved employment prospects for Hong Kong workers nor created higher positions for experienced workers. In fact, as mentioned above, largely because of significant differences in wage levels between Hong Kong and the mainland, Hong Kong workers were soon displaced by workers in the Pearl River Delta.

14. These surveys asked respondents who had worked on the mainland during the 12 months before the enumeration whether they were "still required to work there in their present job at the time of enumeration." But the two sets of statistics do not differ significantly from each other, and thus in the following discussion we will focus on statistics concerning "Hong Kong residents who had worked in the mainland of China during the twelve months before enumeration."

15. For example, there is no evidence to suggest that many Hong Kong residents have chosen the option of settling on the mainland for the purpose of career development. As we shall see in the following discussion, the number of Hong Kong residents working on the mainland started to drop from 2004 onwards, while between 2004 and 2007, the number of Hong Kong residents who residing or staying substantially on the mainland only increased from 472,900 to 500,700. See Census and Statistics Department, Thematic Household Survey Report 35: Characteristics of Hong Kong Residents Having Resided/Having Stayed Substantially in the Mainland of China, Hong Kong, Census and Statistics Department, 2008, p. 19.

16. The Census and Statistics Department adopted a different classification scheme for occupations in earlier surveys. The percentage of Hong Kong residents who work on the mainland as "production and related workers, transport equipment operators and labourers" accounted for $42.7 \%$ in 1988. Given that there has been a change in the way occupations are classified, it is difficult to compare the data. But it is safe to say that Hong Kong residents working on the mainland are becoming less and less likely to be engaging in production-related jobs.

17. Stephen W.K. Chiu and Tai-lok Lui, Hong Kong: Becoming a Chinese Global City, op. cit. 


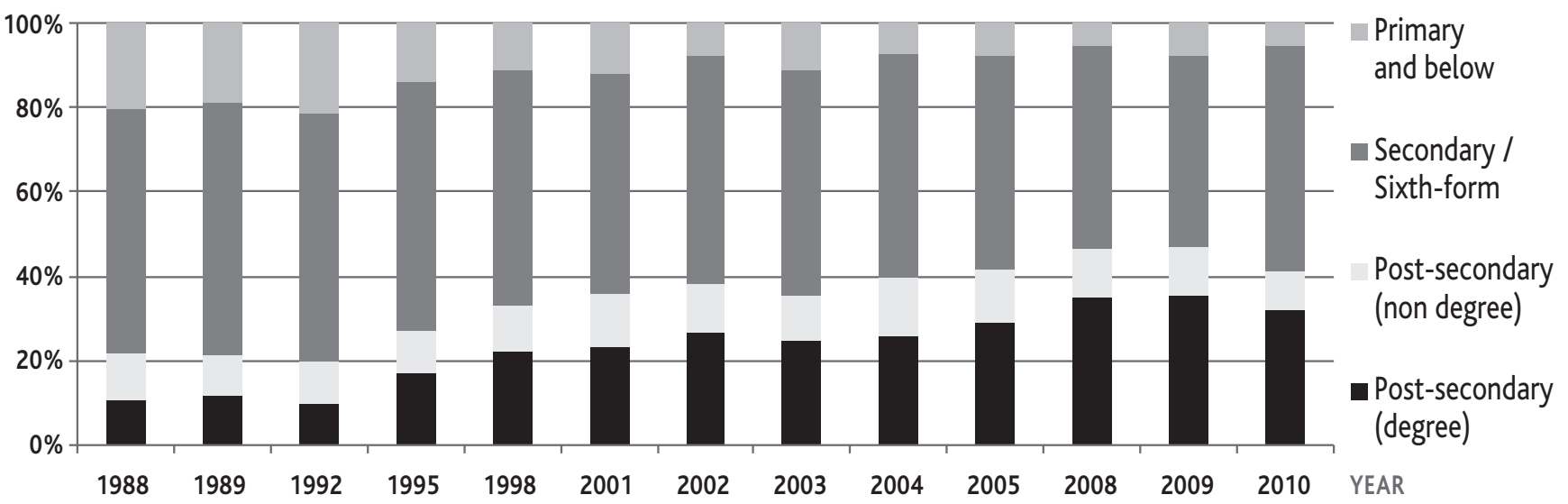

Source: Census and Statistics Department, "Hong Kong Residents Working in the Mainland of China," various years.

\section{Graph 4 -The age structure of Hong Kong residents working in mainland China}

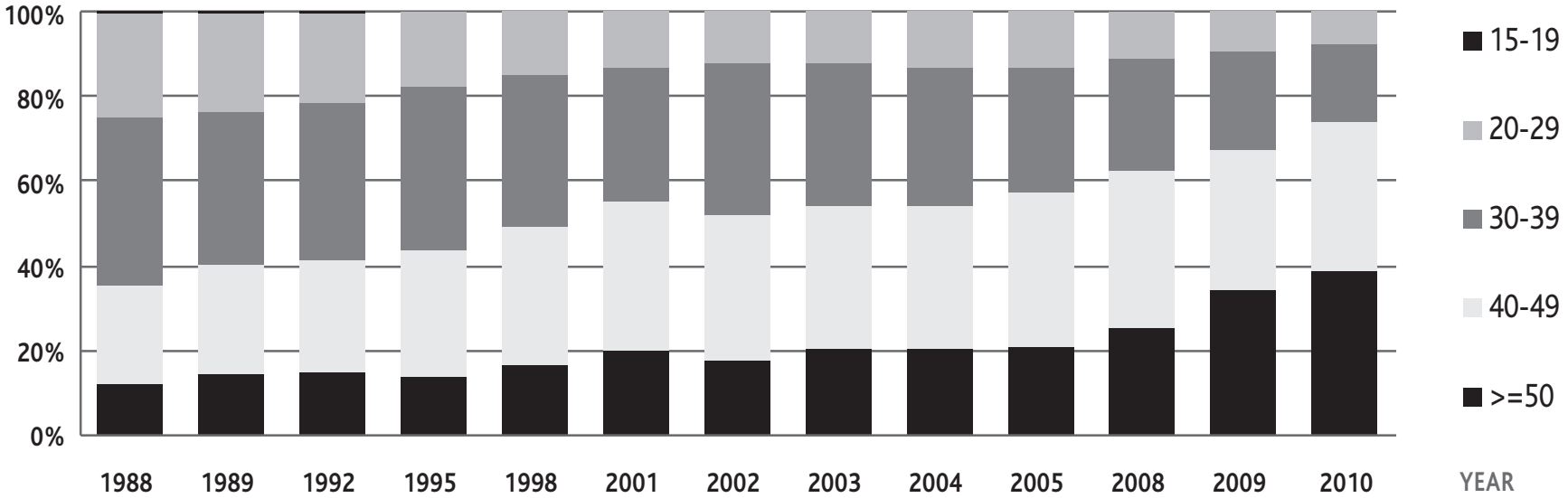

Source: Census and Statistics Department, "Hong Kong Residents Working in the Mainland of China," various years.

By 2005 , in terms of occupation, $81 \%$ of all Hong Kong residents working on the mainland took up the jobs of "managers and administrators" and "professionals and associate professionals." It is clear that the strength of Hong Kong's human resources does not fall into simple manual and/or non-manual work but rather in the handling of managerial and professional work. This is partly the advantage Hong Kong continues to enjoy vis-à-vis the reforming Chinese economy and its newly developed enterprises. With a well-developed institutional structure of commerce and a long-established system of various kinds of professional practice, Hong Kong has a lot to offer to China. This was particularly so at the time when China first re-opened its door to the world economy, and it is still the case as a rapidly growing and developing Chinese economy looks for business and professional services to facilitate and support new development. This demand for skill and expertise from Hong Kong is shown in the distribution of occupations among Hong Kong residents working in the mainland. The majority work as "managers and administrators" and "professionals and associate professionals."

Largely as an outcome of the demand for skill and expertise from Hong Kong, the people working on the mainland are increasingly college graduates. Graph 3 shows the education background of Hong Kong residents working on the mainland. Whereas in the late 1980 s only about $20 \%$ had completed post-secondary (degree or non-degree) education, the figure has gone up to about 40\% since 2004. Increasingly, educational credentials have become an important qualification for Hong Kong residents to obtain a job in China. What we have discussed seems to have summed up the changing spatial division of labour between Hong Kong and the mainland at the regional and national levels. With Hong Kong's specialisation in business and professional services and the broadening of its areas of investment into the tertiary sector on the mainland, the demand for services offered by Hong Kong residents working across the border falls primarily in those areas where they have their competitive advantage. Non-credentialed production-related workers are unlikely to find opportunities in this changing regional setting. Opportunities in the mainland are primarily created for those who are better educated and working in managerial, administrative, and professional occupations. It is apparent that these opportunities are not open to all persons irrespective of their background and area of competence. In this regard, the changing occupational composition of Hong Kong residents working on the mainland reflects the on-going economic relationship between the two places. The earlier phase of industrial relocation, and thus the creation of openings for Hong Kong's craft workers and even machine operators, ended long ago. Increasingly, the demand for skill and expertise has primarily focused on managers, 
Graph 5 - Median age of Hong Kong's working population and of Hong Kong residents working in mainland China

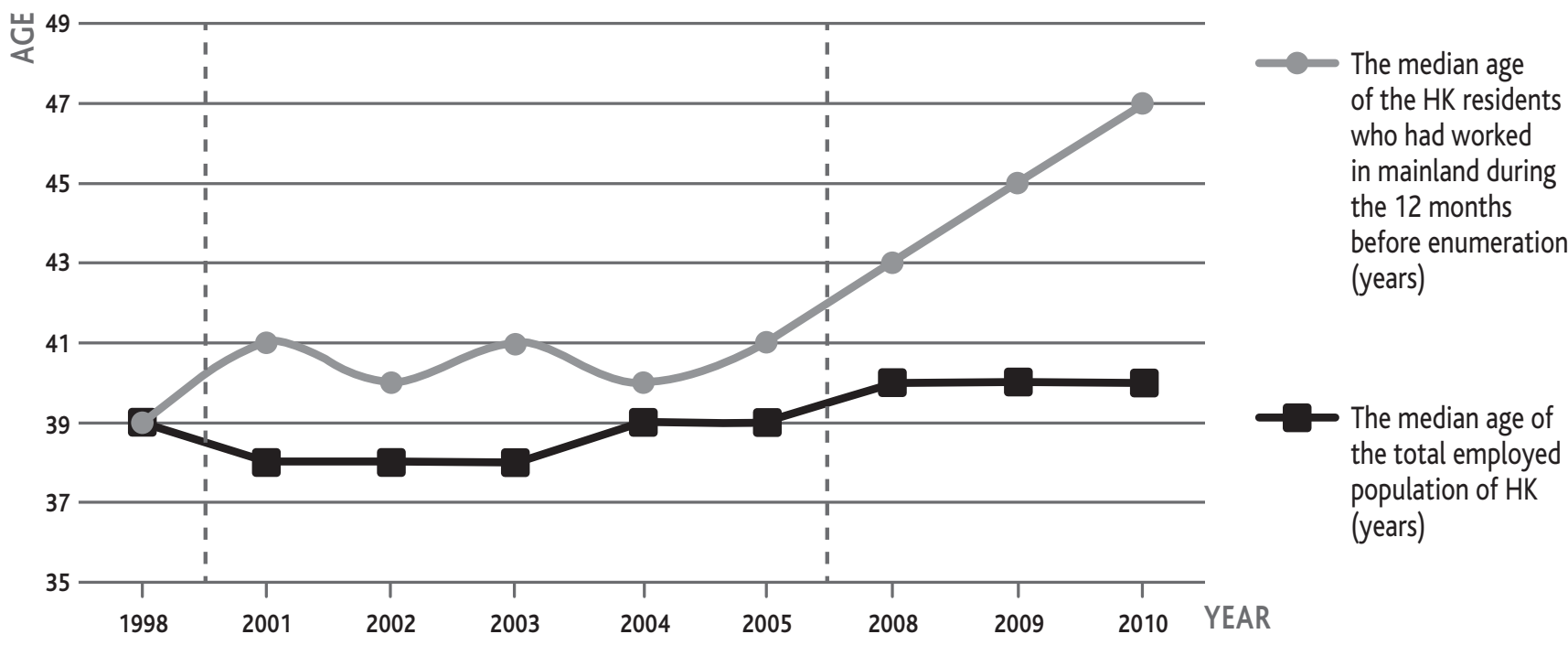

Source: Census and Statistics Department, "Hong Kong Residents Working in the Mainland of China," various years.

\section{Graph 6 - Hong Kong residents who had worked as employees on the mainland during the 12 months of enumeration by employer}

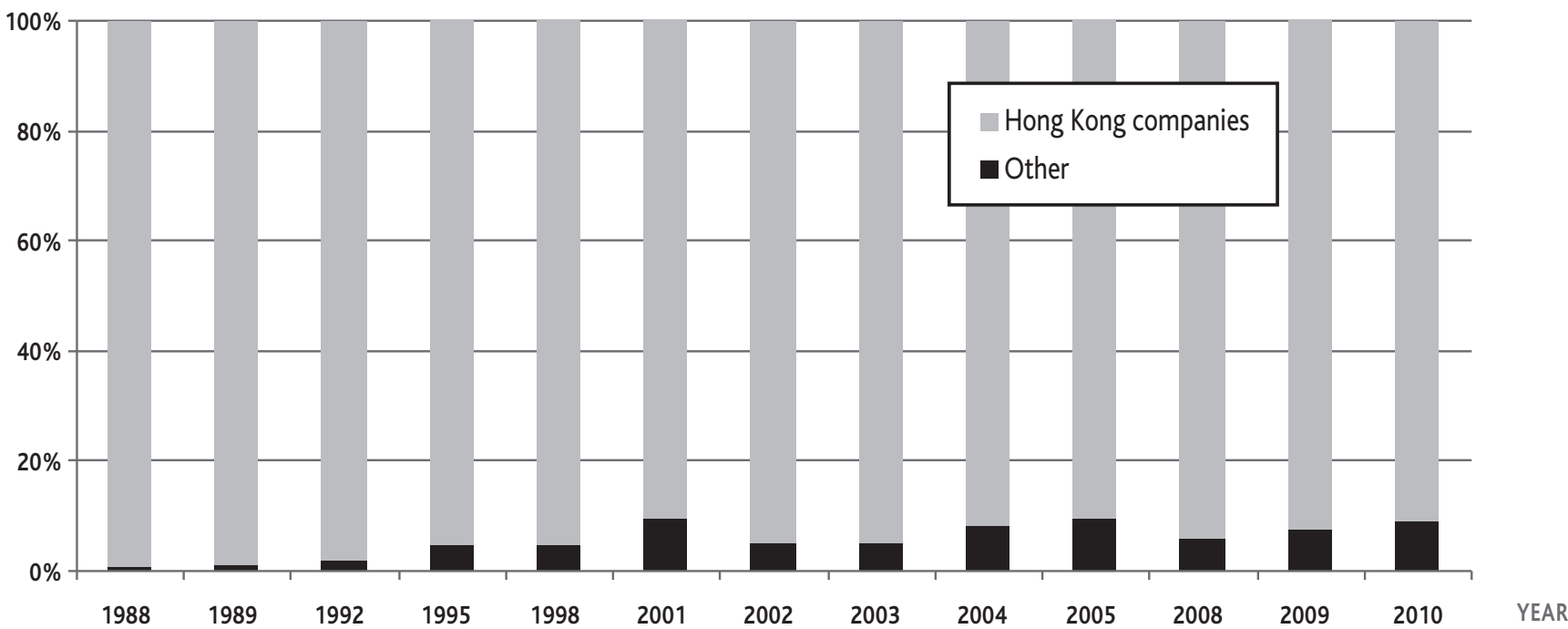

Source: Census and Statistics Department, "Hong Kong Residents Working in the Mainland of China," various years.

professionals, and administrators. While those mobile (i.e., with highly transferable skills, professional knowledge, and work experience) managers, professionals, and administrators have benefitted from growing integration with the Chinese economy, the rest of the working population faces an uncertain future. ${ }^{(18)}$

A closer look at the age structure of Hong Kong residents working on the mainland further alerts us to the fact that, not only have the total number been declining and the opportunities primarily confined to better-educated managerial and professional employees, but those who are able to capture opportunities in China are likely to be experienced middle or upper-level managers and professionals. Graph 4 shows the age structure of Hong Kong residents working on the mainland. Whereas in the survey conducted in 1988 about one-fourth of them fell into the age brackets of $15-19$ and $20-29$ years old, from 2009 onwards the percentage has fallen to less than $10 \%$. In 2010 , almost three-fourths (74\%) of the Hong Kong residents working on the mainland were aged 40 or above. There is no indication that one needs to start early in China in order to capture the opportunities there, ${ }^{(19)}$ and the above statistics suggest that inexperienced junior managers and professionals are not what employers are looking for.

18. On the differences between a mobile and an embedded middle class, see Tai-lok Lui, "Fear of falling," in Carola McGiffert and James Tang (eds), Hong Kong on the Move: 10 Years as the SAR, Washington, D.C., Center for Strategic and International Studies, 2008.

19. The 2010 survey suggested that almost half ( $45.2 \%$ ) of the Hong Kong residents who had worked on the mainland and were still required to work there first started after 2000. See Census and Statistics Department, Social Data Collected Via the General Household Survey Special Topics Report No.53: Hong Kong Residents Working in the Mainland of China, Hong Kong, Census and Statistics Department, 2010, p. 37. 
This emphasis on experience and seniority is best shown in the changing median age of Hong Kong residents working on the mainland (see Graph 5). Compared to the median age of the working population in Hong Kong, it is observed that those who work on the mainland are significantly older. In 1998, the median age for both the local working population and residents working on the mainland was 39 years old. While the former has remained quite steady in the range of 38-40 years old, the latter rose to 41 years old in 2005, and since then has risen further to 47 years old in 2010. Despite repeated calls for the younger generation to open themselves to opportunities across the border, the reality seems to be the other way round - opportunities in the mainland are primarily for those in senior positions and experienced in their work. Opportunities for younger managers and professionals in their $20 \mathrm{~s}$ are in fact rather limited.

In sum, economic integration with the mainland has provided Hong Kong and its people with new opportunities. In the course of China's economic reform and the opening of its economy to foreign investment, Hong Kong has played an important role in connecting the mainland with the outside world. Furthermore, Hong Kong has taken the opportunity and made use of the labour supply across the border to transform the Pearl River Delta into a "world factory." Upon the production base that manufacturers developed, Hong Kong's manufacturers find themselves operating on a larger scale that keeps them competitive without major technological upgrading. These developments have brought new employment opportunities to Hong Kong's working population. Very often it is assumed that this trend toward the opening of new opportunities will continue as China maintains its course of further liberalisation and globalisation. Yet, as shown above, the trend towards an expansion of employment opportunities on the mainland has reversed since 2004; there was a drop of 68,900 persons working on the mainland between 2004 and 2010. Equally important is that such opportunities became more restrictive around the same period. The kinds of jobs available to Hong Kong people have turned towards a focus on managerial, professional, and administrative work. Correspondingly, Hong Kong people looking for such opportunities are expected to obtain post-secondary education. The openings available seem to be senior positions requiring work experience, as reflected in the statistics that the median age of Hong Kong residents working in China rose to 47 years old in 2010.

The question of whether development in China and the changing relationship between Hong Kong and the mainland have provided the SAR with new opportunities or otherwise is not a matter of yes or no. It is quite true that as a result of economic integration, new opportunities have been created. Yet, we have also observed that the trend has reversed and the window is no longer wide open.

\section{How big is the so-called "China opportunity"?}

Indeed, if we take a further look at the current state of economic integration in terms of Hong Kong residents finding employment opportunities across the border, there are two striking features alerting us that the socalled "China opportunities" may fall significantly short of the projected picture. First, Hong Kong residents can only find employment opportunities on the mainland through local organisations. Graph 6 sums up the way in which Hong Kong residents found their employment on the mainland in 19882010. It shows that an overwhelming majority (within the range of $90.4 \%$ 99.2\%) were employed by companies in Hong Kong. The Census and Statistics Department provides no further details on what is meant by "companies in Hong Kong." They could be local companies in the narrow sense of being managed and owned by local capital, but they could also refer to Hong

\section{Graph 7 - Usual place of work of Hong Kong residents working in mainland China}

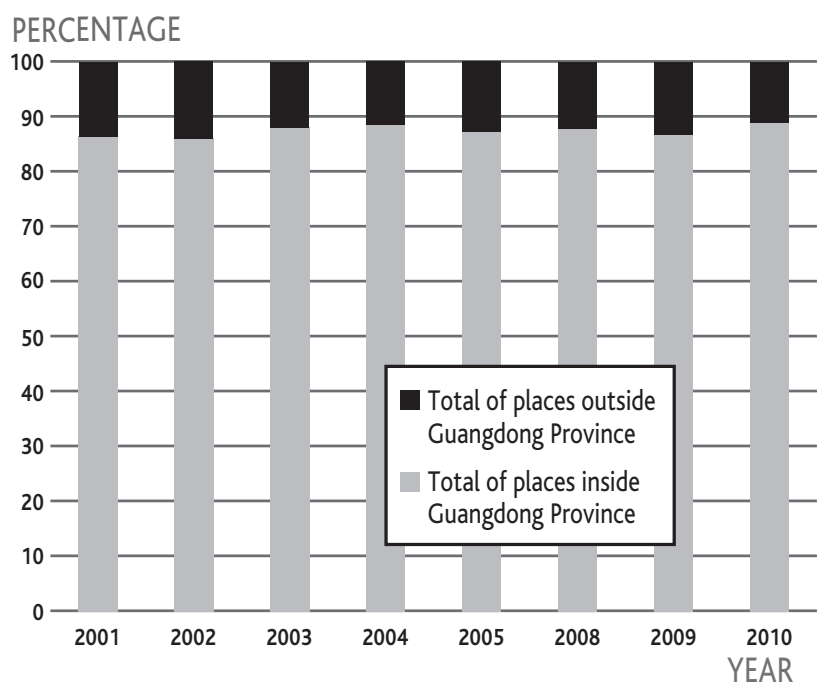

Source: Census and Statistics Department, "Hong Kong Residents Working in the Mainland of China," various years.

Kong-based companies owned by capital from any part of the world. We do not know if many have been employed by mainland and overseas companies based in Hong Kong. But the available data do point to the fact that the overwhelming majority of Hong Kong residents working on the mainland have to find their jobs in China through a locally-based recruitment process. No matter how open the opportunities in China, Hong Kong residents have to seize them via job searches in the local context. In this regard, Hong Kong residents working on the mainland are most likely to be existing staff assigned to China postings. Strictly speaking, they have not participated in China's labour market in the sense of making themselves available for employment and competing with other local Chinese in the recruitment process. Their prospects of finding employment in the mainland depend significantly on the demand of Hong Kong-based companies (locally owned or run by Chinese or overseas investment). They do not go into China and look for jobs, but rather remain firmly tied to Hong Kong's local context in search of opportunities on the mainland. To a large extent, the social barrier in the labour market between Hong Kong and the mainland has not been lowered.

Second, most of the Hong Kong residents working on the mainland work within the province of Guangdong (see Graph 7). The percentage of people working outside Guangdong has never exceeded 15\%. Shenzhen, Dongguan, and Guangzhou are likely to be their places of work. The extent of economic integration at the national level is much lower than originally envisaged. Graph 7 informs us that despite all these years of economic interaction between Hong Kong and the mainland, most economic activity continues to focus on the region, and business is conducted within the provincial boundaries. The picture conjured up in Graph 7 is not one of intensive integration at the national level. Rather, Hong Kong people find their "China opportunities" mainly within Guangdong. A lot of the potential for Hong Kong people in a vibrant Chinese economy has not been fully realised.

It is interesting to observe that in terms of employment, the so-called "China opportunity" for Hong Kong people continues to be Hong Kongbased, and its scope primarily confined to Guangdong. True, even within such limits, it has brought about many employment opportunities, especially to experienced managers and professionals. Yet, such opportunities, 
instead of continuing to expand, seem to have reached certain thresholds - the quantity (in terms of the number of persons employed) is decreasing, its geographical spread is largely stagnant, and its scope is increasingly confined to managerial, professional, and administrative jobs. Contrary to the narrative of beikao zuguo, the rise of China in terms of an expansion of its market, an increase in its consumption power, and its move towards further globalisation has not really helped change the picture depicted above.

Of course, many would quickly point out that the so-called "China opportunity" should not be narrowly defined as the opportunity for Hong Kong people to find employment on the mainland. Equally significant would be the demand of Hong Kong's business services by Chinese corporations (e.g., the growing number of IPOs in Hong Kong's stock exchange) and the sharp increase in mainland tourists visiting Hong Kong. The inflows of such economic activity no doubt contribute to Hong Kong's economic growth. Yet, their impact requires critical assessment and evaluation. For instance, the arrival of mainland tourists, increasing at a rate of about 6 million persons per year since 2009, is expected to drive business and employment in the retail trade, food and beverage services, and other tourism-related services. While the impact on employment is significant, (20) inbound tourism valueadded statistics (in terms of its contribution to Hong Kong's GDP) is less impressive. In 2005, inbound tourism's contribution to GDP was 2.4\%. It increased only slightly to $2.6 \%$ in 2009 . (21) The tourism industry is relatively labour intensive, and its value as a major sector for driving economic growth and development is contentious.

In short, while "China opportunity" in terms of creating employment on the mainland for Hong Kong people has started to slow down and to focus on managerial and professional jobs since 2004, it has begun to assume the form of inflow of economic activity and people into Hong Kong since the SARS attack and the launch of the CEPA. This change in the direction of flow of economic activity and in the mode of interaction between Hong Kong and the mainland seems to have escaped most people's attention. It is subtle and redefines the meaning of "China opportunity."

\section{Concluding remarks}

In this paper, we examined one aspect of the changing relationship between Hong Kong and the mainland in the course of regional and national integration. It is shown that, despite the creation of opportunities by China's re-entry into the world economy since 1978, Hong Kong is gradually finding itself drying up in terms of its ability to further capitalise on the mainland's rapid economic development. The so-called "China opportunity" has been shrinking (in a quantitative sense) and has become rather exclusive (in terms of the kinds of jobs available to Hong Kong people). This probably explains why the narrative of beikao zuguo is increasingly losing its appeal to the public. This is very different from the picture many once envisaged of Hong Kong's growing influence, at least economically, at the regional and the national level. It is also different from the suggestion put forward by those who believed that closer cooperation between Hong Kong and the mainland would guarantee the latter's prosperity. While developments in the real world seem to have fallen short of expectations, this has not stopped senior government officials from using the "China opportunity" rhetoric to promote regional as well as national integration. Furthermore, they continue to rely on the narrative of a vibrant Chinese economy to boost optimism in Hong Kong's future economic development. How people, especially the younger generation, will respond when such promises fail the reality check is difficult to say. But it is likely to become a source of social tension and frustration as Hong Kong and the mainland further integrate at both the regional and national levels.

\section{Tai-lok Lui is Professor at the Sociology Department of the University of Hong Kong. \\ Sociology Department, The University of Hong Kong, Jockey Club Tower, Centennial Campus, Pokfulam Road, Hong Kong (tloklui@hku.hk).}

20. It was suggested that in $2000-2009$, "28.4\% of all new jobs in Hong Kong created were in the tourism sector." See Irina Fan and Joanne Yim, "Hong Kong Tourism Industry," Economic Focus, Hang Seng Bank, 20 April 2011, p. 2.

21. Census and Statistics Department, "Tourism Satellite Account for Inbound Tourism of Hong Kong," Hong Kong Monthly Digest of Statistics, March 2011, p. FA10 